\title{
Suicide in Leo Tolstoy's Anna Karenina (1877), Johann Wolfgang von Goethe's Sorrows of Young Werther (1774), and Chinua Achebe's Things Fall Apart (1958)
}

\author{
Baker Bani-Khair \\ Hashemite University, Jordan \\ Abdullah K. Shehabat \\ Tafila Technical University, Jordan \\ Raja Al-khalili \\ Hashemite University, Jordan \\ Husam Al Momani \\ Hashemite University, Jordan
}

\begin{abstract}
This paper studies the idea of identity loss and suicide in three novels that have different cultural backgrounds. These novels are Leo Tolstoy's Anna Karenina (1877), Johann Wolfgang Goethe's Sorrows of Young Werther (1774) and Chinua Achebe's Things Fall Apart (1958). The paper discusses the theme of suicide in all of these three novels through concentrating on one major aspect which is individuality. Okonkow in Things Fall Apart, Anna in Anna Karenina and Werther in Sorrows of Young Werther have suffered and struggled hard to live as happy individuals in society. Each one of them had dreams and ambitions which they tried to realize. Individuality seems one of the strongest motives behind their own dreams. However, all of them have failed in their pursuit of having an individual life away from social constraints and pressures. The study points out the social, psychological, political factors and conditions that lead to the individual's identity loss. All these protagonists were looking for establishing an unfettered personal identity, but they all lost their dreams on the way and the result was a downfall, a loss of individuality, and most importantly a tragic life which pushed them to commit suicide.
\end{abstract}

Index Terms -Achebe, individuality, patriarchy, suicide, Tolstoy, Goethe

\section{INTRODUCTION}

Anna Karenina, Sorrows of Young Werther, and Things Fall Apart have many social and political themes in common. However, the theme of suicide remains one of the most important ones. In this paper, we will discuss the theme of suicide in all of these three novels through concentrating on one major aspect which is individualism. Okonkow in Things Fall Apart, Anna in Anna Karenina, and Werther in Sorrows of Young Werther are all fictional characters who lived as individuals in societies that have their historical, cultural, political and social conditions determining their fate. Each one of these protagonists has suffered and struggled hard to live as an individual in his or her society. Moreover, each one of them has dreams and ambitions which they try to realize. Individuality seems to be one of the strongest motives behind their own dreams. However, all of them have failed in their pursuit of having an individual life away from social constraints and pressures. In addition to the fact that all the protagonists in the selected novels were looking for establishing an unfettered personal identity, but they all eventually lost those dreams. The result of their efforts was a downfall, a loss of individuality, and most importantly a tragic life that prompted them to commit suicide. The protagonists suffering could be attributed to the discipline of individuals practiced by modern society and an interpretation of the text could be explained by applying Foucault's theories on the relationship between knowledge and power and the role of discipline in social control through social institutions. Mitchell Foucault in Discipline and Punish (1975) states that:

Punishment, then will tend to become the most hidden part of the penal process. This has several consequences: it leaves the domain of more or less everyday perception and enters that of abstract consciousness; its effectiveness is seen as resulting from its inevitability not from its visible intensity; of being punished and not the horrifying spectacle of public punishment that must discourage crime; the exemplary mechanics of 
punishment changes its mechanisms. As a result, justice no longer takes public responsibility for the violence that is bound up with its practice. (P.9)

Foucault's attempts to understand the development of the penal code explains the relationship between the individual and society. The social system throughout history both ancient and modern does not tolerate delinquent behavior and the three protagonists prove the results of acting against social norms. From a social perspective, the experience of the protagonists is a turning point in their lives and the stability that is at the beginning of their lives erodes at the end of it. The narratives appeal to the reader's imagination and draw a calculated sense of a distance between the main characters and the readers. The protagonists are immersed in and frightened by the consequences of their behavior.

\section{SUICIDE IN THE THREE NOVELS}

\section{A. Suicide in Anna Karenina}

Suicide in all of these three literary works seems to meet in one direction. First of all, Anna's suicide seems to fit the context of a modern capitalist and hierarchical class society, which is politically and socially restrictive and oppressive. Despite the fact that social oppression appears so subtle in the novel, the reader can see the boundaries and fetters of such a culture which imposes constrictions on the individual. We can see the dimensions of Anna's new situation in her society. Unlike Vronsky, her lover, Anna had to suffer from patriarchy, simply because she got deprived of her old external relations with friends who were important people whom she knew. Anna also lost that social decency and interest she received from society. Therefore, Tolstoy condemns "patriarchy" as the reason for her suffering because Vronsky did not suffer in the same way as Anna did. In fact, Vronsky received little social criticism compared to Anna.

The lack of social justice explains Anna's jealousy of Vronsky's relations. For Anna, the double standards imposed on her by society made her aware that Vronsky is free and has open access to social contacts and relations. Gary Adelman refers to this point in Anna Karenina: The Bitterness of Ecstasy (1993) when he states that:

Tolstoy oscillates between moral condemnation and love for his heroine, and the richness of the novel lies in the equilibrium he achieves between those contrary impulses, reflected in Anna's often repeated formula "guilty but not to blame." However, in the opening segment of part 4, Tolstoy shows more prejudice against his heroine than love for her. The progress of her deterioration has advanced considerably along with her pregnancy. She experiences embittered resentment and flashes of hatred for Vronsky-a jealousy of his freedom, his self-possession, and his separate existence. To her this is infidelity, and her jealous fits have a chilling effect on Vronsky. (P.77)

It is noticeable from the novel that Anna lost her honor simply because the Russian society and law at that time did not allow divorce to happen until the plea of adultery was made before the court. In The History of Sexuality: An Introduction (1976), Foucault explains the intricate relationship between strict moral codes and the punishment it warrants especially in the nineteenth century (3). According to Foucault, sexuality has been considered a taboo as a subject and therefore a difficult obstacle against gaining individuality. For the protagonist, her sense of freedom relied on being liberated from norms imposed on sexuality. Karenina knew that Anna would lose everything if she left him simply because Anna lost her honor before the law when she proved herself as guilty. The incident illustrates how social oppression against women is quite significant when looking at Anna's case of suicide. Anna's character could be regarded as a composite character that illustrated the frustrations felt by many individuals and especially women of her own time. Gareth Jones in "George Eliot's Adam Bede and Tolstoy's Conception of Anna Karenina" states that previous drafts of the novel show that the Russian novelist modeled Anna after Hetty Sorrel in Adam Bede both in terms of physical appearance and psychological sensitivities (p. 475). Moreover, they are both victims of a society that has double standards.

Anna's inability of having a structured family directs the reader's critical assessment of the failure of constitutional marriage which led to Anna's frustrations in the first place. The fact that Anna's life was completely ruined because her first marriage did not make her happy is an example of the difficulty that a person has to endure to meet certain political and social standards in order to be accepted as an individual, which is another form of political and social domination against women. While one cannot say for sure if Anna's suicide and downfall at the end was an outcome of societal pressures, but the readers still see how Anna's moving away from society was because she followed her own self as 'Anna', the individual. While society was watching Anna's behavior and condemning her as being irrational, Anna realized the fact that she began to lose her identity as a woman because of the loss of control over her fragmented inner self. At some point in her life, Anna had to avoid social contact after she decided to go with Vronsky. Also, Anna was humiliated and criticized in public. As the plot moves on, Anna's character began to erode and waste away, and the only thing she can do is to end her life and commit suicide.

Anna's decision to love Vronsky is an example of how individuality as a personal choice clashes with the social, familial or traditional norms. Anna's dreams of freedom and individuality were in conflict with the norms that led to a loss of identity. Anna's new love is basically seen as a deviation from both the society and the self. Her new relation to Vronsky was part of her love dream which she pursued because she wanted to live as a happy individual. She did not know that personal freedom comes with a cost because social norms and traditions might be in a contradiction with her own dreams. However, she was able to see the point that individualism is also hard to get and that it demands sacrifice and change. But she wanted to search for herself even with the high risks because she knew that it was a struggle with 
the self. According to Amy Mandelker, Anna Karenina is an example of how “Tolstoy's use of shadow imagery and its connection to the shadow figure of folklore suggests the implementation of a mythological archetype and a sustained symbolic system" and thus the novel no longer becomes "as an exemplary realist work" and becomes "closer to a symbolist mode." (p. 48) Therefore, the novel emphasizes the story of Anna as a cautionary tale and could be read as a warning to readers about other individuals who may face the same problems if they chose to follow the example of Anna. Even in his other work, Tolstoy emphasizes fear as a primordial emotion. For example, in "Sevastopol in May 1855 " he describes fear in with eloquent and basic simplicity: "But when fear has once entered the soul it does not easily yield to any other feelings" (p. 47). Throughout the novel, Tolstoy has worked to rewrite the past of the major character and change her fate but to no avail.

Anna started to discover as time moved on in her new relationship with Vronsky that her character as an individual is suffering from a gradual waste of both her internal psyche and body. Anna stood in the middle between her aspirations, her lost dreams and her own social and political position in society. But she neither achieves her own love and romantic dream, nor does she keep her own decency of being a respected woman in society. Anna's attempts to achieve individuality were no more than a deviation from both the self and the identity at the same time. Her attempts to be a free individual in the society led her to be more restricted and ultimately an outcast. Even though Anna's first marriage was governed by social decency and formality which was restricting her freedom and personal life, her new love was more restrictive both socially and psychologically because it led to a more psychological entrapment which Anna could not bear to live with at the end of her life journey.

\section{B. Suicide in Sorrows of Young Werther}

Suicide in Sorrows of Young Werther is represented as an escape, failure, and an ultimate weakness to confront the residuals of the new romanticism which complicates the structure of identity within the domain of individualism. Goethe in the epistolary novel shows a true mark of genius because he was able to make the specific universal and the universal specific (Swales 2002, viii). Werther's love story and suicide raise questions on how individuality becomes more difficult to be attained and measured in a society that is still suffering from postwar psychological effects. Werther's letters are almost similar to reminiscences of a soldier writing to his family from afar and he seems to be more as a lover agonized by sexual frustration. The novel raises many questions concerning the protagonist's behavior because he seems to be living in an isolated world of his own. In one of the letters, he writes: "It is true, I am only a wanderer, a pilgrim on this earth! But are you more?" (p. 70). His haunting statement serves as a timely reminder of the uneven development of his story and is as a narrative device foreshadowing his displacement.

The story is represented to readers in a new modern style. Although it was written in the eighteenth century, the story mixes different approaches to individualism ranging from the gothic fantasy and realism to romanticism. From a psychological perspective, love in Sorrows of Young Werther seems to be represented as a fantasy dealing with love which failed to accomplish its role as a stabilizing force in society. The theme of love was also a central one in his shorter work Novella which was published in 1828. However, suicide in Sorrows of Young Werther is actually an escape from reality rather than society. The suicide here appears as madness or obsession on a personal and psychological level rather than as being connected with a social motive as we can see with both Okonkow and Anna. Werther's infatuation with Lotte seems to be a form of madness in the psychological sense, which makes it different from Anna's love for Vronsky. Even though the protagonists share the same psychological obsession with love, each one of them, however, has a different meaning and purpose for love. They do agree though on the definition of love which is characterized as a form of repressed sexual desires and a desperate need to attract others. Moreover, both look for different meanings and approaches to individualism because their cultures are different.

Werther's love for Lotte is idealized to the extent that Werther finds his life impossible to continue after feeling that Lotte will no longer be his own love. Being psychologically tortured by the perfection he sees in Lotte and his love's hallucinations, Werther decided that he should kill himself. According to Warrick, the idealization of Lotte remains the reason behind many critical views that fail to see sufficient clues that "suggest that there is more to Lotte's character than either of the two narrators admits" (p.129). Werther is similar to Anna in Anna Karenina because each one of them loves and misses their respective partners more. Both Werther and Anna feel that the other partner is not as devoted and sincere as they are. However, the complexity of this love lies in the fact that Werther's love became an obsession which later evolved into a form of madness, and towards the end of the novel it became a form of self-destruction. Despite the fact that Anna is a totally different example of romantic dreams of love and individuality from Werther, both of them are still good examples of the difficulty of achieving a true definition of the self. There remains also a difference between Anna's approach to individuality from Werther's approach to love and individualism.

\section{Suicide in Things Fall Apart}

Suicide in Things Fall Apart could be interpreted from a post-colonial perspective because it portrays the loss of the tribal system in Africa as well as the physical authority and domination of the "white masters" as a consequence. Okonkow's suicide is both an external and internal juxtaposition to colonization. It is worth noting here that suicide in this novel is very much politicized because it reflects a personal tragedy within a broader theme of social and political oppression represented by colonization. Okonkow's failure in society is actually seen as a representation of the downfall of both society and the individual. The downfall of the individual is, in fact, a parallel to the downfall of the tribal 
system of the society. Achebe in the novel wanted to write a counter- narrative to redress "the reductive and distorted representation of traditional African cultures" (p.161). Okonkow's suicide is viewed as a reaction against domination and social corruption. Suicide can be viewed as a criticism of society and also as a reaction against the failure of the political, social and also individualistic relations within the society.

While Anna's suicide at the end represents an escape from the social life and a failure to fit in a society where an individual has to lose the freedom to lead a different life from others, Oknokow in Things Fall apart is an example on how the downfall of the individual is correlated with the downfall of society. Okonkow's suicide at the end is a surrender to an overwhelming political life based on racism and colonization. The complexity of Okonkow's situation within the society lies in the fact that the system of the tribe has to be based on relationships, friendship, and physical power rather than onan actual systematic society. The novel shows us how Okonkow had to struggle hard between his manhood and his own dignity presented to the reader as a form of individuality.

The loss of Okonow's status in society is similar to Anna's loss of her social status in the society. However, the situation is a little bit more complex in Oknokow's story simply because Okonow's identity and his tribe's identity are assimilated at the end to fit into the newly colonized world. Anna had also the same identity crisis that we see in Things Fall Apart, since the struggle that Anna had to go through was more with the self, and since it looks completely personal and social. However, the threads of patriarchy are inextricably woven into the two cultural backgrounds even though this appears extremely different and obvious in Okonkow's culture as patriarchy dominates the whole scene. Robert Wren refers to masculinity in Things Fall Apart as "the male principle" that "dominates the first part of the novel." According to Wren "Only Unoka, Okonkow's father, shows a love of song and music, and he is contemptuously described as agbala, or "Woman", because, lazy and improvident, he has never had wealth or prestige enough to take the ozo title. He will never join the community of ancestors that, with the living, is the clan" (p. 33).

Patriarchy in Things Fall Apart is represented in the form of social pressure. Patriarchy also plays important in Tolstoy's novel. The opening lines of the novel clearly illustrate the types of stories that are typical of broken homes. The lines state that "All happy families resemble one another; each unhappy family is unhappy in its own way." (p.1) Anna found it difficult to choose between following the social and traditional patterns of life which appear psychologically unsatisfactory or her own desires as a woman who can love whom she wants to love. Vronsky seemed to her much more of a dream of fantasy of love which she actually never had. Anna's suicide could be seen as an exit from a suffocating entrapment. Her love dream was brutally killed at the end. Adelman refers to the social dilemma that Anna had to go through in society:

From the perspective of this celebrated doctrine, the moral scheme of Anna Karenina appears to be a contrast between two lives: one that is driven by passion to imagine that happiness id the attainment of desire, the other driven by despair to find peace in religious conversion. Anna's suffering derives from the nature of passion. The loss of respectability, social ostracism, the longing for her reason-these are secondary to the insatiability of the will, which is the central tragedy of human life. The Levin plot demonstrates that earthly life can be complete and satisfying; it exemplifies Tolstoy's moral law: thou shalt live in the country, work hard, be dutiful to family, renounce passion, and believe in God. His point seems to be that people are made miserable by the combined efforts of destiny and society when they disobey any part of this law (p.117).

Similarly, suicide in Things Fall Apart can also be looked at as the outcome of guilt and shame that Okonkow wanted to get himself rid of because of his participation in killing his son and also because of his failure in his approach to lead his tribe. There is nothing positive in Okonkow's relations to the others even in a father and son relationship. His savage and irrational behavior is the tragic flaw that finally led him to self-destruction. Taiwo refers to Okonkow's brutalities in spite of his brief moments of kindness as ones "which influence the course of events in the novel and finally alienate him from his people. It is, for example, because of his harsh treatment of Nwoye and his part in the killing of Ikemefuna that tension develops between Oknkow and his son, leading to a complete breakdown in communication between the two" (p. 120). Here, in particular, the vulnerability of the individual comes to the fore.

Also, another drive for his suicide is that he came to realize that fact that savagery is something destructive and leads to a sense of abandonment. This is an important psychological drive behind his suicide because Okonkow realized at the end that he is now "out of place" as Taiwo states that the decision to kill the court messenger brought Okonkow the realization that he "ought to have known a long time before-that he is alone. It is the thought that the unity of the tribe is gone forever and that there is no hope of reviving the old martial spirit that drives him to commit suicide" (p.121).Achebe illustrates towards the final episodes in the novel that the individual at the end could not possibly achieve a victory even in his own society which eventually succumbed to the realities of assimilation to white culture. The elder men's response to the District Commissioner's questions indicates an ironic statement on Okonkow's death:

"It is against our custom," said one of the men. "It is an abomination for a man to take his own life. It is an offense against the Earth, and a man who commits it will not be buried by his clansmen. His body is evil, and only strangers may touch it. That is why we ask your people to bring him down, because you are strangers" (p.207).

The resolution of the moral conflict is therefore not surprising to readers because the saddened reply of the elder man implies his distress at the price of personal and social harmony.

\section{CONCLUSION}


All three novels evoke the theme of suicide which was the resolution that all of the three protagonists made at the end to isolate themselves from society. Okonkow, for example, had to leave his own tribe as an exile punishment for the crime he committed. His regret of the crime committed against his son, although he knew it was part of the oracle, was an epiphany on the greatness of his mistake. Anna also had to desert her society and put up with all the social criticism just to be with Vronsky. She alienated herself from the society around her in order to be with her lover. Werther had also to distance himself from the community and live in isolation restricting himself to those he writes letters to.

The behavior of all the three of them explains how suicide was more of a self-decision, and that it was all either socially or politically driven as we can see with Okonkow and Anna. Also for the three characters, the lack of reason, and the loss of balance was a major drive behind their suicide. The readers can detect Anna's love as actually moving in the wrong direction from the very beginning. Also, Okonkow's suicide was a result of a failure to maintain peace within his own family members and his tribe. Thus, Okonkow was driven by his own tribal mentality rather than his reason or intellect. Werther's love was also no more than an obsession which totally lacks reason or even mature emotions. The authors who represented in their novels the universal theme of suicide have been praised for their method of building psychological tension and emphasizing the belief that an individual is by necessity conditioned to the requirements of his social milieu. The external events that are portrayed with great physical detail shift to their inner significance for the major characters.

\section{REFERENCES}

[1] Achebe, C. (1994). Things Fall Apart. New York: Anchor Books.

[2] Adelman, G. (1990). Anna Karenina the Bitterness of Ecstasy. Boston, MA: Twayne.

[3] Goethe von, Wolfgang, J. (1999). The Sorrows of Young Werther, Elective Affinities, Italian Journey, Faust, Novella, Selected Poems and Letters. London: Everyman

[4] Jones, G. (2015). “George Eliot's Adam Bede and Tolstoy's Conception of Anna Karenina.” Modern Language Review, 100:191-199.

[5] Mandelker, A. (1993). Framing Anna Karenina: Tolstoy, the Woman Question, and the Victorian Novel. Columbus: Ohio State UP.

[6] Mandelker, A. (1990). "The Woman with a Shadow: Fables of Demon and Psyche in Anna Karenina." Novel: A Forum on Fiction, 24 (1): 48-69.

[7] Martin's Wren, Robert M. (1980). Achebe's World: The Historical and Cultural Context of the Novels of Chinua Achebe. Washington, D.C.: Three Continents.

[8] Swales, Martin, Swales, E. (2002). Reading Goethe: A Critical Introduction to the Literary Work. New York: Camden House.

[9] Snyder, C.J. (2008). The Possibilities and Pitfalls of Ethnographic Readings: Narrative Complexity in Things Fall Apart. College Literature, 35, 154-174.

[10] Taiwo, O. (1976). Culture and the Nigerian Novel. New York: St.

[11] Leo, T. (1982). "Sevastopol in May." The Raid and Other Stories. Trans. Oxford: Oxford UP.

[12] Leo, T. (1982). Anna Karenina: (The Margelios World Republic). (2014). Trans. Mariam Schwartz. Yale: Yale UP.

[13] Warrick, E. K. (1978). “Lotte's Sexuality and Her Responsibility for Werther's Death.”Essays in Literature, 5(1): 129-135.

Baker Bani-Khair, is currently an associate professor of English literature at the Hashemite University, Jordan. He has published several articles on different aspects and topics that mainly deal with American and British Literature, cultural studies, and Film. His research interests are varied and multifarious, but he especially focuses on the 19TH Century American novel and poetry, 1960s and 1950s American films, Gothic Literature, culture, and history.

Abdullah K. Shehabat, is an associate professor of American Literature and Translation studies at Tafila Technical University. He has been teaching at different universities in Jordan and abroad. As part of his sabbatical leave expertise in Bahrain, he taught courses in Arabic language for non-native speakers. His major areas of research interest include American literature, postcolonial literature, African American literature and Translation studies. He published a number of referred papers in internationally recognized journals.

Raja Khaleel Al-Khalili is Associate Professor at Hashemite University, Jordan. Her main research interests are in feminist studies and ethnic diversity in American and English literature. She has authored a book entitled, The Dialectic of Theatrical Space and Domestic Space: Modern British and American Drama 1900-1939. The author has also published several papers on modern and contemporary literature, comparative literature, Arabic literature, cultural studies, and gender studies.

Husam Al-Momani is an associate professor of Rhetoric and linguistics at the Department of English, Hashemite University. His research interests primarily focus on linguistic theories, discourse analysis, pragmatics, and sociolinguistics. He is also interested in studying English as a second language. He published scholarly articles on second language learning and teaching. 